\title{
Decentralization, jurisdictional spaces and regional development in Nigeria
}

\author{
Yemi Adewoyin ${ }^{* 1,2}$, Lekan M. Sanni ${ }^{3}$, Aina T. Adeboyejo ${ }^{4}$ \\ ${ }^{1}$ University of Nigeria, Nigeria \\ ${ }^{2}$ University of the Witwatersrand, South Africa \\ ${ }^{3}$ Federal University of Technology, Minna, Nigeria \\ ${ }^{4}$ Ladoke Akintola University of Technology, Nigeria
}

With the cliché of bringing development closer to the people, the Nigerian government, like many African countries, institutionalized the process of creating Local Government Areas (LGAs) and used it as a policy instrument for more than four decades. This study adopted a survey research design using data on 24 local development indicators, aimed at appraising the efficacy of this policy as a development tool. Quantitative analysis using Principal Component Analysis and its statistical outputs of initial eigenvalues and orthogonal scores shows that $36 \%$ of the LGAs ranked lowest on the dimensions of development before the creation of additional jurisdictions in 1996, while $20 \%$ and $44 \%$ ranked intermediate and highest respectively. Post-partitioning, the proportions were $24.4 \%, 39.4 \%$ and $36.4 \%$ respectively, thus providing evidence of the positive development impact of decentralization. The findings, however, throw up issues of distributional inequality in public investments which could be addressed by conscious planning efforts.

Key Words: Decentralization, Jurisdictional Space, Jurisdictional Partitioning, Regional Development, Distributional Inequality, Nigeria

Article Info: Received: March 4, 2020; Revised: May 13, 2020; Accepted: November 5, 2020; Online: November 30, 2020;

\section{${ }^{*}$ Corresponding author}

Address: Department of Geography, University of Nigeria, Nigeria

Phone: +2348062932175 | Email: yemiadewoyin@yahoo.com

(C)2020 Human Geographies; The authors

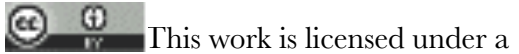

Creative Commons Attribution 4.0 International License. DOI:10.5719/hgeo.2020.142.6 


\section{Introduction}

Development, by its nature, is not territorially equal. Several explanations have been offered for this phenomenon. These include theoretical postulations and models rooted in the economics of factors of production (Mahalanobis, 1953; Lewis, 1954; Myrdal, 1957; Rostow, 1960; Fei \& Ranis, 1961), including some with a spatial component (Perroux, 1955; Hirschman, 1958; Friedman, 1966). More recently, explanations were found in the alternative perspective that development inequality among places is a function of differentiation in natural endowment and resources among places, the spatial organization of the places and their prevailing mode of production, notably political economy (Smith, 1987). Policies and practices to address inequality in regional development are as varied as the explanations for its causes. With a landmass in excess of $9,000 \mathrm{~km}^{2}$, and wide diversity, not only in ecology and relief but also in spatial resources and actual economic development among its component locales, addressing regional inequality in development in Nigeria has been a policy issue for about five decades (Federal Republic of Nigeria, 1970). In the country's Third National Development Plan (1975-1980), conscious efforts at addressing these diversities became more pronounced with the re-organization of the Federal Ministry of Agriculture to promote rural development, investments in rural electrification, the establishment of River Basin Development Authorities (RBDAs), and the decentralization of governance through the creation of States and Local Government Areas (LGAs) (Ikporukpo, 1983; 1986; Adeniyi, 1985). These policies were aimed at addressing a situation where some parts of the country were experiencing rapid economic growth while other parts were lagging (Federal Republic of Nigeria, 1975). Decentralization was "expected to generate development in the different parts of the country through deliberate locational policies" (Ikporukpo, 1986:129).

A substantial number of studies have highlighted some of the benefits associated with political decentralization, particularly in developing and transitional countries (Smith, 1985; Esman \& Uphoff, 1988; Ichimura \& Bahl, 2009; Bartlett et al., 2013). In Madagascar, for example, Tahina (2015) reported that it is increasingly being used as a tool for poverty reduction and fostering social inclusion among the citizenry. The process is also believed to have substantially shaped government political structures in Africa where many states are increasingly transferring power, resources and responsibilities to sub-national political entities, in addition to enhancing equitable distribution of public services and increased citizen participation (Almond et al., 2003). Another argument canvassed in support of political decentralization is its potency for encouraging and promoting economic growth and regional development in heterogeneous countries by facilitating efficient utilization of limited resources (MartinezVazquez \& Mcnab, 2003; Schneider, 2003). It is believed that decentralization usually comes with a greater level of economic development by encouraging increased citizen participation (Bahl \& Linn, 1992; Bailey, 1999; 2002; 2004; Bartlett et al., 2013). Increased or multilevel governmental structures arising 
from political decentralization allows for a certain category of public services to be provided in accordance with the preferences of different local units (Biela et al., 2012). Decentralization is, however, not without its negative consequences. These range from inefficiency, a multiplicity of bureaucratic structures, wastefulness, worsening spatial inequality and the outright hijacking of governance by local elites (Okafor, 1987; Eaton, 2001; Wunsch 2001; Olowu, 2007; Abdullahi \& Mahuta, 2012; Danjuma \& Kwanga, 2012).

Prior to Nigeria's independence in 1960, demands for the decentralization of governance were mostly made for the promotion of citizens' inclusion in governance and direction of their local affairs. The demand for LGAs started in the Eastern Province in 1948 with approval from the Eastern House of Assembly in 1950 (Ola, 1984). The Western Region followed in 1952. It was not until 1976 that the LGAs were conceived as instruments for promoting regional development. The 1976 Local Government Reform which officially spelt out the roles of the LGAs hinged on the justification that "the state governments have continued to encroach upon what would normally have been the exclusive preserve of local governments,...(and) excessive politicking had made...progress impossible, consequently there has been a divorce between the people and government at their most basic levels,...(therefore) the federal government was essentially motivated to stabilize and rationalize government at the local level which necessitates the decentralization of some significant functions of state government to local government for rapid development" (Oyewo, 1987). Essentially, the 1976 local government reform not only recognizes the local governments as a tier of government that can affect the lives of citizenry positively, it equally sees the local governments as units of decentralization for rapid development at the local level (Federal Republic of Nigeria, 1976; Oyewo, 1987).

With the national jurisdictional partitioning exercises of 1963, 1967, 1976, 1987, 1991 and 1996 to strengthen the decentralization of governance in Nigeria, states and local government creation appears to be the most widely used regional development tool in Nigeria. The population has also come to accept this as the norm and continuously demands for more. The demands are more vociferous in areas where the population perceives itself as being marginalized. From 300 LGAs in 1976 to 716 between 1979 and 1983 before the additional 416 were declared as unconstitutional by the succeeding government, the number of LGAs in Nigeria stands presently at 774. Between 1999 and 2018, and hinging their actions on the need to take development closer to the people, a couple of states, notably Lagos, Osun and Oyo in Southwest Nigeria, have further partitioned existing LGAs in their states and christened them Local Council Development Authorities (LCDAs). While these LCDAs function essentially as LGAs, the nomenclature is an attempt by the states not to be seen as breaching the Federal Constitution that vests the rights to partition existing jurisdictions to the National Assembly. Against this background, this study seeks to appraise the efficacy of decentralization, as exemplified by jurisdictional partitioning for the creation of LGAs, as a tool for addressing the spatial inequality in development among regions in Nigeria. Specifically, the study seeks to provide an answer to the 
question of whether or not decentralization brings development. The study becomes particularly important as more states in Nigeria are gravitating towards the LCDA option because of the technicalities involved in getting the National Assembly to approve additional LGAs for them. Across many African states and other developing countries, the LGAs are also a popular form of local governance (Lago-Penas et al., 2011).

As a concept, decentralization has enjoyed a robust discussion but has varied meanings and interpretations in the literature. Although it is considered a complex and multidimensional process, it is increasingly seen as a harbinger of development, especially in the developing countries where it is closely related to a principle of local government security, participation and accountability (Rondinelli, 1981). The concept is understood to mean the process of devolving political power, responsibilities and authorities from central government to quasiindependent or local government authorities (Rondinelli, 1999; Eryilmaz, 2011; Sjamsuddin \& Noor, 2012). Decentralization is said to be conceptualized in many ways and dimensions depending on the degree of delegation and autonomy transferred to local actors (Joseph, 2014). The focus of decentralization, aside from being multidimensional, includes increasing the efficiency and effectiveness of governmental activities and enhancing popular participation in government and the development process (Sjamsuddin \& Noor, 2012). It is a process which gives more levels of inclusion and participation to elected local representatives in decision making, formulation and implementation of policies. Decentralization is considered a process, set of political reforms or series of political restructuring that aims to transfer responsibilities, resources and authority from the central to other lower levels (Falleti, 2004). To Kim (2008), the aim of political decentralization goes far beyond the perceived devolution of powers as it focuses on enhancing the provision of public service and delivery of public welfare through good governance.

It is argued that political decentralization has different forms as well as dimensions. The forms of decentralization include de-concentration, devolution and delegation (Ozmen, 2014). De-concentration is used to refer to a central government that distributes its responsibility to provincial institutions within the scope of a particular policy. However, the central government still retains authority over its field offices as well as exercises that authority through the hierarchical channels of its central bureaucracy. De-concentration moderately allows more autonomy than centralized systems (Schneider, 2003). It is a system where the central government is allowed to transfer some of its decision making and execution authorities to administrative heads of sub-units in its hierarchy (Eryilmaz, 2001). Under de-concentration, the central government is allowed to shift some responsibilities from some of its officials at the capital city to those working at the various regions, provinces or districts, although still retaining the power of supervision (Rondinelli, 1999). Devolution on its part involves a system where some form of authority for decision making over financial and management issues are transferred to quasi-autonomous units of local government, especially those with corporate status (Ozmen, 2014). This is mainly 
operational in instances where municipalities have elected mayors or councillors, raise revenues and hold independent authority over investment decisions under a system where local governments have clearly defined and constitutionally recognized geographical boundaries. This type of administrative structure underlies political decentralization (Rondinelli, 1999). Devolution is believed to provide the most significant degree of autonomy for local units, and the local units are only accountable to the central government in instances where the central government has overriding responsibility (Schneider, 2003).

The third form of political decentralization is called delegation. It is regarded as a more extensive form of decentralization as political powers and responsibilities are transferred from the central government to the local governments or semi-autonomous political organizations. Although the local governments are not directly controlled by the central government, they are accountable to it (Schneider, 2003). Instances of delegation include situations when government creates public enterprises or corporations that are saddled with responsibilities over specific services such as housing and transportation and transfers its authorities or functions in these areas to the organizations, giving such corporations broad discretion in managerial decision making (Rondinelli, 1999). In many respects, a decentralized system has three levels of governments which are the national or central, regional or state, and local or municipal authorities (Brancati, 2006). Each of these levels of government is conferred with some level of both executive and legislative powers by the constitution. Its dimensions include political, administrative and financial reforms. Explaining these dimensions, Kose (2004) opined that its political dimension includes the transfer of administrative, legislative and judicial autonomy to local governments, while the administrative dimension refers to the transfer of some form of classical functions of the state to the quasi-autonomous public institutions. The financial component has to do with intergovernmental fiscal relations, especially in countries where the constitutions give powers over taxation, budget and expenditure rights to the units in a federal system of government (Ozmen, 2014). The local government system in Nigeria exhibits the features of all the forms of decentralization, but its characterization is more of devolution than both delegation and de-concentration.

Nigeria operates a three-tiered federal system of government with the central government at the apex and the states as the second tier. The local government is the third tier and is subsumed within the jurisdictional space of a state, just as the state is a federating unit of the federal government. As governments play two significant roles of protection and production in most societies (Buchanan, 1974), organization of space and spatial structures becomes the bedrock on which the business of governance rests. According to Cox (1972), all governments, irrespective of scale, operate within legally bounded spaces. The nature of space has, however, remained something mysterious to social enquiry (Harvey, 1973). If viewed in absolute terms, space becomes a thing in itself with an existence independent of matter. That is a container serving as the field of human action (Mabogunje, 1980). Relative space, on the other hand, proposes that it be 
understood as a relationship between objects and therefore exists only because objects exist and relate to each other (Harvey, 1973). In this instance, the objects dictate the boundaries of space. In relational space, space is perceived as containing and representing within itself other types of relationships which exist between objects (Mabogunje, 1980). Jurisdictional space is absolute in nature, and unlike other kinds of spaces, it is typically stable and not subject to rapid change (Austin et al., 1987; Honey, 1983). It is within this space that public goods and services are supplied to the population by the government (Coates et al., 1977). The Local Government Areas (LGAs) in Nigeria are therefore jurisdictional spaces within which the protection and productive functions of government are provided to promote local development.

\section{Methodology}

\section{Study Area and Scope}

Nigeria, has an estimated population of 200 million, a landmass of about $925,000 \mathrm{~km}^{2}$, and comprises 37 States, including the Federal Capital Territory, Abuja, and 774 LGAs. These states are grouped along geographically contiguous lines into six political regions consisting mostly of homogeneous ethnic groups or ethnic groups of similar cultural characteristics. Oyo State, Southwest Nigeria, with its headquarters at Ibadan, was purposively selected for this study. The choice of Oyo State is predicated on its history as one of the oldest states in Nigeria and undoubtedly, the most partitioned. At independence, Nigeria had three regions; Northern, Eastern and Western. The present-day Oyo State was the hub of the then Western Region and its capital city of Ibadan was the headquarters of the Western Region. The region witnessed its first partitioning exercise in 1963 with the creation of the Midwest Region. Lagos was excised from the region in 1967, Ogun and Ondo were created from it in 1976 while Osun was created in 1991. With each of the state creation exercises, the number of LGAs was also affected. In the last state creation exercise of 1996, the LGAs in Oyo State increased to 33 from 25. Again, Oyo State is vital as a case study as it has the highest number of LGAs/LCDAs in the country (68). When the LCDAs are discounted, the state has 33 LGAs, the second-highest in the country. The scope of this study only covered the period between the partitioning exercise of 1996 and 2016 before the creation of the LCDAs. This was done on the assumption that the 20-year period was long enough to assess improvements in the level of development across the LGAs. The LCDAs were created only about four years ago and would not significantly contribute to regional development in the short term. Furthermore, the National Assembly was yet to recognize the LCDAs constitutionally.

\section{Data Types, Sources and Collection}

The study adopted a survey research design that employed both primary and secondary data types. A number of 24 local development indicators peculiar to 
the study area, the study data were collected using a combination of field survey, extraction from documentary sources and map analysis. The datasets were on educational indicators, healthcare, transportation, communication and infrastructures, population, level of urbanization, industry and services. Data on education ware obtained from the records of the State Universal Basic Education Board (SUBEB) and the Teaching Service Commission (TESCOM). Healthcare data were sourced from the records of the State Ministry of Health, while population data were sourced from the National Population Commission. Other datasets were collected from documentary sources, filed survey and/or computed from existing records. The datasets were collected for 1996 to depict the level of development before the partitioning exercise of 1996, and for 2016 to represent the present state of development post-partitioning (Table 1).

\section{Data Analysis}

The 24 indicators were appropriately coded and subjected to the multivariate statistical technique of Principal Component Analysis (PCA). The PCA was employed to identify the underlying dimensions in the variables in both the pre and post partitioning periods. The Principal Component analysis technique was employed because its primary hypothesis is that each of the original variables is a product of different combinations of standard dimensions and that these basic principal components (dimensions) are substantially fewer than the observed variables.

Table 1. Development Indicators

\begin{tabular}{ll}
\hline \multicolumn{1}{c}{ Class of Data } & \multicolumn{1}{c}{ Indicator } \\
\hline Education & 1.Primary school per population \\
& 2.Primary school teacher per population \\
& 3.Percent enrolment \\
& 4.Percent female enrolment \\
& 5.Secondary school per population \\
& 6.Availability of tertiary institution \\
& 7.Number of state/general hospital \\
Healthcare & 8.Number of medical doctors \\
& 9.Road distance to state capital \\
Transport & 10.Mode of intra-city transport \\
& 11.Density of tarred road \\
12.Availability of public phone \\
13.Availability of daily newspaper \\
14.Availability of postal services \\
15.Availability of rec facilities \\
16.Spread of functional electricity \\
17.Availability of pipe borne water \\
18.Population \\
19.Population density \\
20.Level of urbanization \\
21.Type of judicial services \\
22.Spread of Banking facilities \\
23.Density of large manufacturing \\
24.Density of pop in primary activities \\
\end{tabular}


In other words, the PCA was used to reduce the 24 indicators to a few uncorrelated variables with which to explain the spatial pattern of development in the study area before and after the local government creation exercise of 1996. In explaining the pattern of development in the LGAs, two statistical outputs from the PCA were employed. These are the initial eigenvalues and the orthogonal scores. The initial eigenvalues are used in identifying the principal components among the initial set of 24 variables based on the total variance explained by each of the initial variables. They were extracted using the minimum eigenvalue of 1.00. Normal varimax rotation of the extracted components was also carried out to achieve a much simpler structure of the rotated coefficients such that each principal component affects a few variables and each variable is correlated with a few principal components. It equally helped in maximizing the number of high and low loading, thereby reducing the number of intermediate scores. The orthogonal scores output of the PCA were employed to group the LGAs into a 3tier development surface. The performance of each LGA on the development surface was thereafter used to explain the LGA's levels of development.

\section{Results}

\section{Pre and Post Partitioning LGAs}

Before the jurisdictional partitioning exercise of 1996, there were 25 LGAs in Oyo State. In 1996, the eight LGAs created from the existing jurisdictions were: Atisbo and Saki East from Ifedapo. The remnant jurisdiction was renamed Saki West. Ibarapa North was created from Ifeloju while the latter was renamed Ibarapa Central. Olorunsogo was carved out of Irepo just as Itesiwaju and Iwajowa were excised from Iseyin and Kajola LGAs respectively. Atiba and Oyo East LGAs were created from Oyo LGA, and the outstanding jurisdiction renamed Oyo West LGA. The old LGAs, including those with new names, retained their administrative headquarters while eight new growth poles were created as the capital cities of the newly formed LGAs (Figure 1 and 2).

\section{Dimensions of Development}

In the pre-partitioning period, four principal components emerged from the data analysis. The four principal components explained $82.999 \%$ of the total variance in the original data set. While the first principal component with an eigenvalue of 15.283 accounted for $63.680 \%$ of the total variance, the second principal component has an eigenvalue of 2.111 and explained $8.796 \%$ of the total variance. The third and fourth principal components have eigenvalues of 1.425 and 1.101 and also accounted for $5.937 \%$ and $4.586 \%$ of the total variance, respectively. Fourteen of the 24 development indicators loaded highly (above 0.500 ) on the first principal component. These indicators are those that measure healthcare, communication, social amenities and services. On the second principal component, all transport indicators and other variables measuring communication and industry loaded above 0.500 while 3 of the education indicators and measures of population and judicial services loaded highly on the third principal component. 


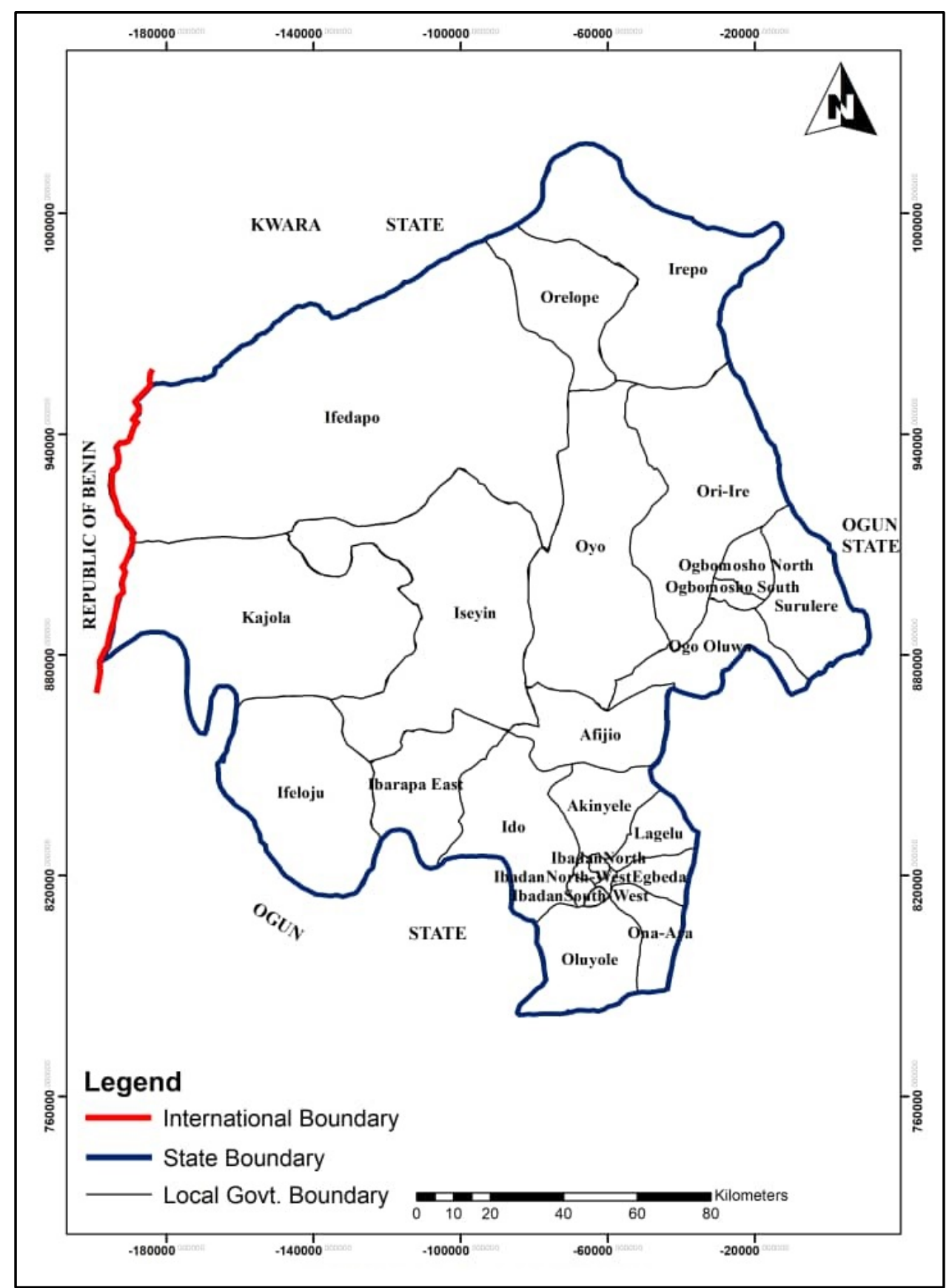

Figure 1. Oyo State in the 25-LGA Era 


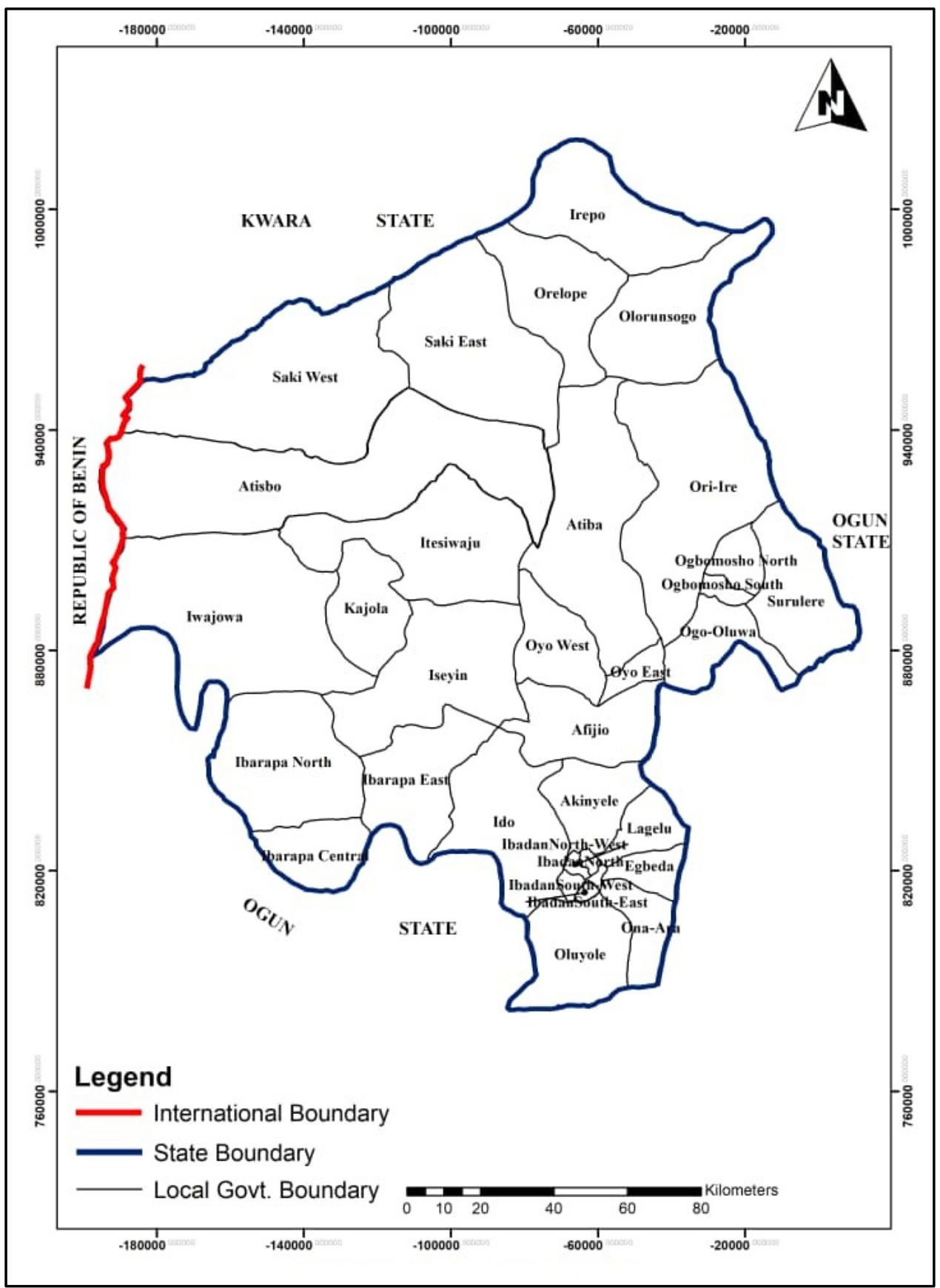

Figure 2. Oyo State in the 33-LGA Era

Only Percent of female enrolment loaded highly on the $4^{\text {th }}$ component. Situating these indicators and their loadings within the context of the classification contained in Table 1, the four principal components (dimensions) underlying the development pattern in the pre-partitioning era were Social Services and Communication, Transport and Industry, Education, and Female Education. 
Four principal components also emerged in the post-partitioning period and accounted for $79.913 \%$ of the total variance in the data set. Whereas the first component explained $60.395 \%$ of the total variance, the second component accounted for $8.113 \%$. The third principal component explained $6.654 \%$, and the fourth component explained $4.750 \%$ of the total variance. Respectively, the eigenvalues of the four principal components were 14.495, 1.947, 1.597 and 1.140. Seventeen of the indicators recorded loadings above 0.5000 on the first component while seven and four indicators had 0.500 and above loadings on the second and third principal components respectively. Only percent female enrolment loaded highly on the fourth component. An analysis of the loadings revealed that, just as in the pre-partitioning era, Social Services and Communication emerged as the first dimension, followed by Transport and Population. Education and Female education emerged as the third and fourth dimensions of development in the post-partitioning era.

\section{Spatial Pattern of Development}

The levels of development of the LGAs were determined using their orthogonal scores from the principal component analysis. The orthogonal scores in this case comprised of a $25 \times 4$ and a $33 \times 4$ matrix based on the rotated factor loadings of the initial 24 variables resolved into four principal components for both the prepartitioning and post-partitioning periods respectively. The orthogonal scores are presented as maps showing how each local government 'performed' (loaded) under each of the four principal components in 1996 and 2016. Based on this performance, a three-tier classification of the LGAs into high, medium and low was carried out using the LGA's scores on each dimension. Orthogonal scores from 0.5 upwards were ranked high, while scores between -0.49 and 0.49 were ranked as medium. Scores less than -0.50 were ranked as low. The summary of the performances is detailed in Tables 2 and 3 .

When analyzing the performances of the local governments on the various dimensions of development, there were notable inconsistencies in their categories in both the pre- and post- partitioning periods. To achieve a composite structure that takes into account the individual performances of each local government on all the dimensions, and be able to categorize the local governments into a 3-tiered development surface for a comparative analysis of movements across the development surface as expected with the creation of new local governments, a cluster analysis was carried out using the orthogonal scores (the $25 \times 4$ and $33 \mathrm{x}$ 4 matrices) as input data. The matrices were analyzed and resolved into three groups using the Squared Euclidean distance method of obtaining a similarity matrix. A 3-level grouping of the local governments according to their performance on the dimensions was thus achieved using the non-hierarchical grouping technique. The results are illustrated in Figures 3 and 4. 
Table 2. Performance of the LGAs on the Dimensions of Development in the 25-LGA Era

\begin{tabular}{|c|c|c|}
\hline Dimension & Performance & Local Government Area \\
\hline $\begin{array}{l}\text { Social Services } \\
\text { and }\end{array}$ & High & $\begin{array}{l}\text { Ibadan North, Ibadan NE, Ibadan NW, Ibadan SE, Ibadan SW, } \\
\text { Afijio, Ifedapo, Iseyin, Ogbomoso North, Ogbomoso South, Oyo }\end{array}$ \\
\hline Communication & $\begin{array}{l}\text { Medium } \\
\text { Low }\end{array}$ & $\begin{array}{l}\text { Irepo, Orelope, Surulere, Oluyole, Lagelu } \\
\text { Kajola, Ifeloju, Ibarapa East, Ido, Akinyele, Onaara, Egbeda, } \\
\text { Ogooluwa, Oriire }\end{array}$ \\
\hline \multirow[t]{3}{*}{$\begin{array}{l}\text { Transport } \\
\text { and Industry }\end{array}$} & High & $\begin{array}{l}\text { Ibadan North, Ibadan NE, Ibadan NW, Ibadan SE, Ibadan SW, } \\
\text { Afijio, Akinyele, Egbeda, Oluyole, Onaara, Lagelu, Ogbomoso } \\
\text { North, Ogbomoso South }\end{array}$ \\
\hline & Medium & $\begin{array}{l}\text { Ifedapo, Kajola, Ifeloju, Iseyin, Oyo, Ogooluwa, Surulere, Orelope, } \\
\text { Irepo }\end{array}$ \\
\hline & Low & Ibarapa East, Oriire, Ido \\
\hline \multirow[t]{3}{*}{ Education } & High & $\begin{array}{l}\text { Ibadan North, Ibadan NE, Ibadan SE, Ibadan SW, Ifedapo, } \\
\text { Orelope, Oriire, Oyo, Ogbomoso North, Iseyin, Ibarapa East, } \\
\text { Ifeloju, Kajola }\end{array}$ \\
\hline & Medium & Ibadan NW, Onaara, Egbeda, Akinyele, Irepo \\
\hline & Low & Ido, Afijio, Oluyole, Lagelu, Ogooluwa, Surulere, Ogbomoso South \\
\hline \multirow[t]{2}{*}{$\begin{array}{l}\text { Female } \\
\text { Education }\end{array}$} & High & $\begin{array}{l}\text { Ibadan North, Ibadan NW, Ibadan NE, Ibadan SE, Onaara, } \\
\text { Ogooluwa, Surulere, Ogbomoso South, Irepo, Ifedapo, Iseyin, } \\
\text { Kajola }\end{array}$ \\
\hline & $\begin{array}{l}\text { Medium } \\
\text { Low }\end{array}$ & $\begin{array}{l}\text { Ifeloju, Oyo, Akinyele, Lagelu } \\
\text { Ibarapa East, Orelope, Ido, Orire, Afijio, Oluyole, Ibadan SW, } \\
\text { Egbeda }\end{array}$ \\
\hline
\end{tabular}

Source: Computed by authors

Table 3. Performance of the LGAs on the Dimensions of Development in the 33-LGA Era

\begin{tabular}{|c|c|c|}
\hline Dimension & Performance & Local Government Area \\
\hline \multirow[t]{3}{*}{$\begin{array}{l}\text { Social Services } \\
\text { and } \\
\text { Communication }\end{array}$} & High & $\begin{array}{l}\text { Ibadan North, Ibadan NE, Ibadan NW, Ibadan SE, Ibadan SW, } \\
\text { Saki West, Iseyin, Ibarapa Central, Oyo West, Oyo East, Afijio, } \\
\text { Ogbomoso North, Ogbomoso South }\end{array}$ \\
\hline & Medium & Atisbo, Atiba, Orelope, Ogooluwa, Surulere \\
\hline & Low & $\begin{array}{l}\text { Irepo, Saki East, Olorunsogo, Itesiwaju, Kajola, Iwajowa, Ibarapa } \\
\text { North, Ibarapa East, Ido, Akinyele, Lagelu, Egbeda, Onaara, } \\
\text { Oluyole, Orire }\end{array}$ \\
\hline \multirow[t]{3}{*}{$\begin{array}{l}\text { Transport } \\
\text { Population }\end{array}$} & High & $\begin{array}{l}\text { Ibadan North, Ibadan NE, Ibadan NW, Ibadan SE, Ibadan SW, } \\
\text { Ido, Akinyele, Lagelu, Oluyole, Onaara, Egbeda, Afijio, Oyo East, } \\
\text { Ibarapa East }\end{array}$ \\
\hline & Medium & $\begin{array}{l}\text { Kajola, Iseyin, Atiba, Oyo West, Ogbomoso North, Ogbomoso } \\
\text { South, Surulere }\end{array}$ \\
\hline & Low & $\begin{array}{l}\text { Irepo, Orelope, Olorunsogo, Orire, Ogooluwa, Saki East, Saki } \\
\text { West, Atisbo, Itesiwaju, Iwajowa, Ibarapa North, Ibarapa Central }\end{array}$ \\
\hline \multirow[t]{2}{*}{ Education } & High & $\begin{array}{l}\text { Ibadan North, Ibadan NE, Ibadan SW, Ibadan SE, Egbeda, } \\
\text { Ibarapa East, Oyo West, Oyo East, Orire, Atiba, Itesiwaju, Kajola, } \\
\text { Iwajowa, Atisbo, Saki West, Saki East, Ogbomoso North }\end{array}$ \\
\hline & $\begin{array}{l}\text { Medium } \\
\text { Low }\end{array}$ & $\begin{array}{l}\text { Irepo, Orelope, Akinyele, Ibadan NW, Onaara, Ibarapa Central } \\
\text { Olorunsogo, Ogbomoso South, Ogooluwa, Afijio, Iseyin, Ibarapa } \\
\text { North, Ido, Oluyole, Lagelu, Surulere }\end{array}$ \\
\hline \multirow[t]{3}{*}{$\begin{array}{l}\text { Female } \\
\text { Education }\end{array}$} & High & $\begin{array}{l}\text { Ibadan North, Ibadan NE, Ibadan NW, Ibadan SE, Onaara, } \\
\text { Ogooluwa, Surulere, Ogbomoso South, Oyo East, Oyo West, } \\
\text { Itesiwaju, Kajola, Iwajowa, Atisbo, Olorunsogo }\end{array}$ \\
\hline & Medium & Saki West, Ibarapa Central, Akinyele, Lagelu, Egbeda \\
\hline & Low & $\begin{array}{l}\text { Ibadan SW, Oluyole, Ido, Ibarapa East, Ibarapa North, Iseyin, } \\
\text { Afijio, Orire, Atiba, Orelope, Irepo, Saki East, Ogbomoso North }\end{array}$ \\
\hline
\end{tabular}




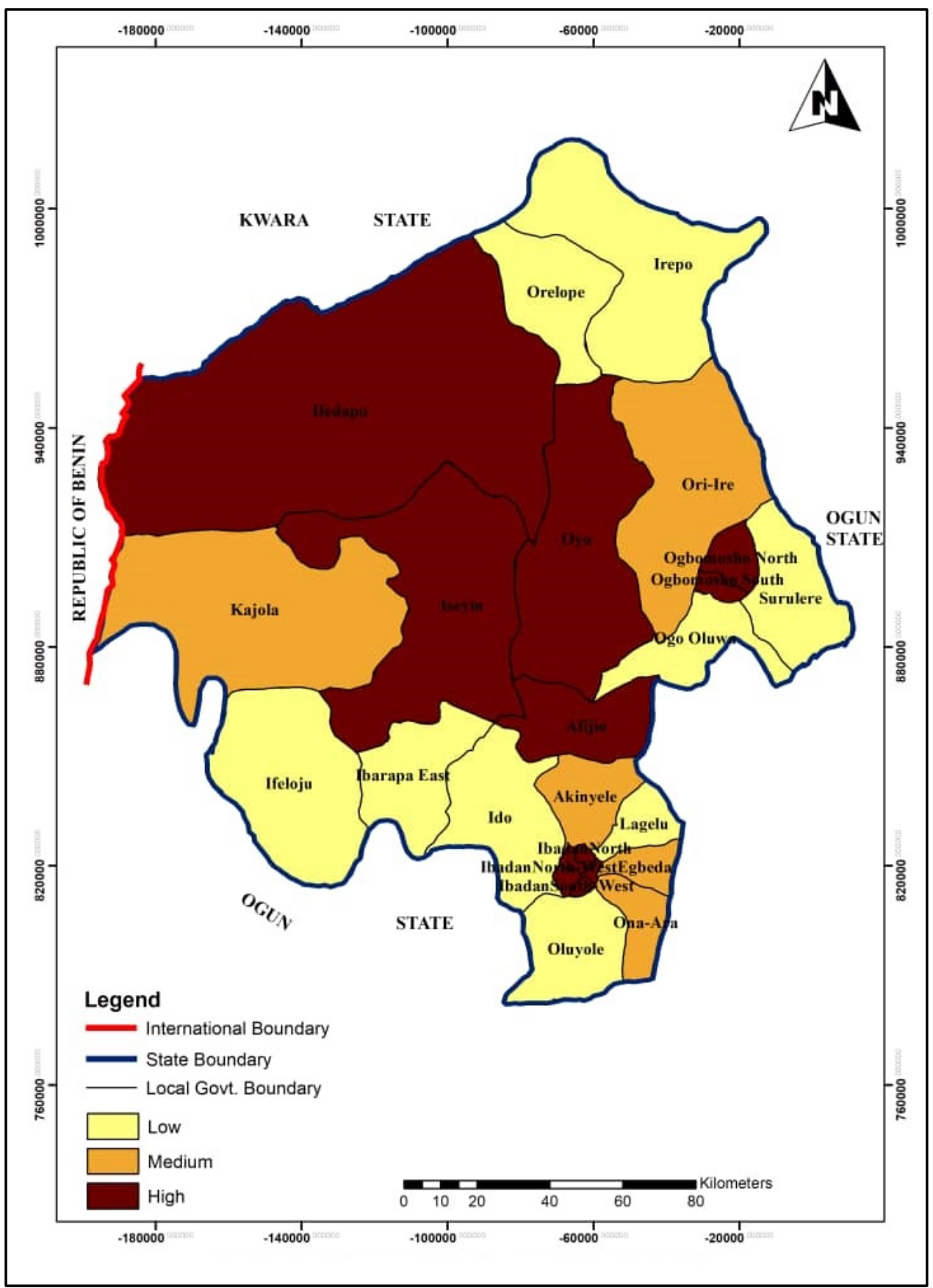

Figure 3. The Pattern of Development in the 25-LGA Era 


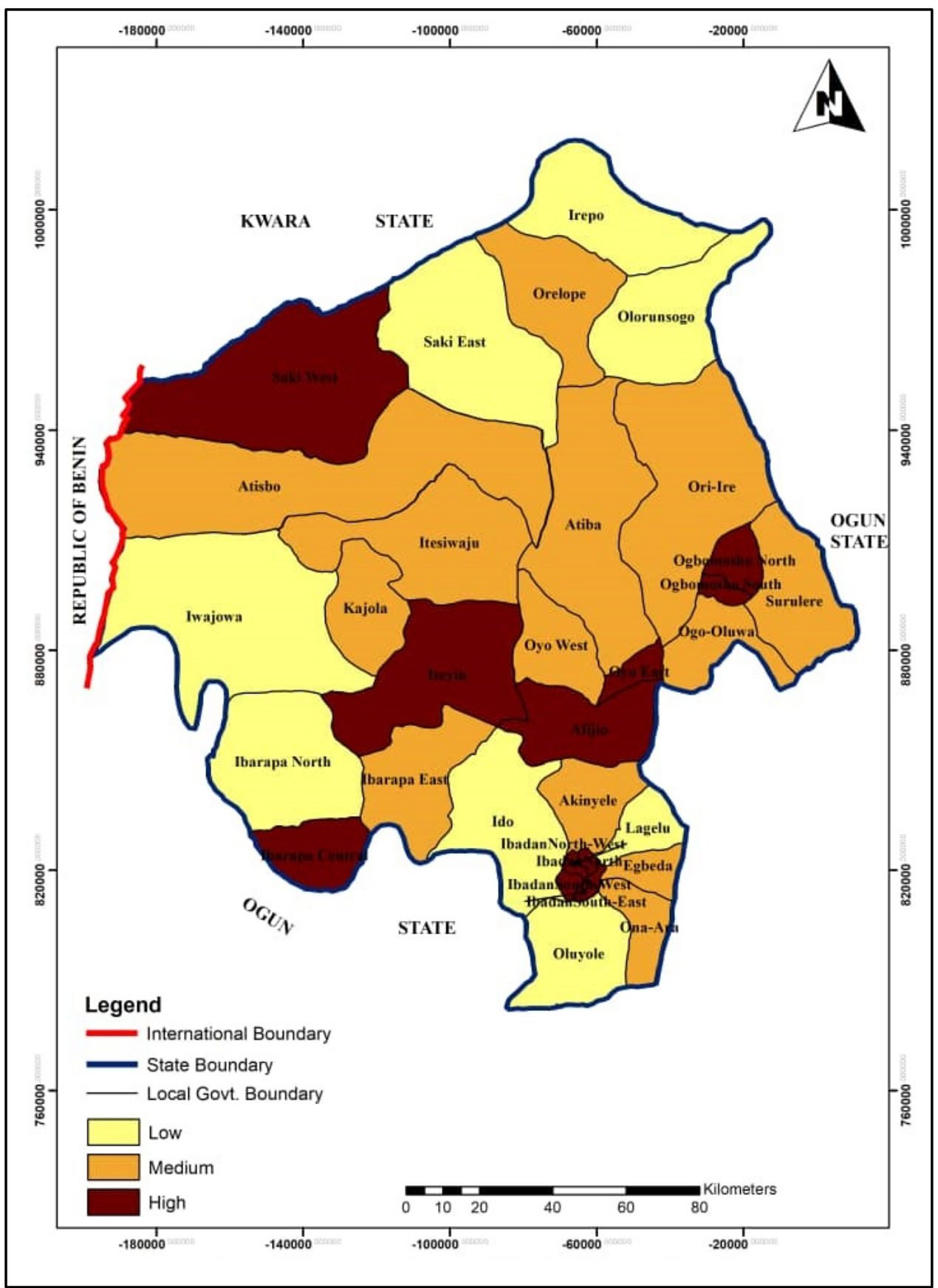

Figure 4. The Pattern of Development in the 33-LGA Era

\section{Discussion}

On all the four dimensions of development in the pre-partitioning era, the five metropolitan LGAs in Ibadan, as well as the two in Ogbomoso, ranked highly except for Education where Ibadan Northwest and Ogbomoso South ranked middle and low respectively, and on the Female Education dimension where 
Ibadan Southwest ranked low. The pattern did not change for the Ibadan LGAs after 20 years, but Ogbomoso North and South dropped to the middle category in the post-partitioning era on the Transport and Population dimension. Ogbomoso North also dropped to the low category on female education. The five Ibadan LGAs and the two in Ogbomoso were not partitioned in the period under review. For the Ibadan LGAs to retain their pre-partitioning era rankings, suggests that there were no changes in the development pattern of the LGAs because they were not partitioned, and no new growth pole was created in that territory. The Ogbomoso case can, however, be explained by the deterioration of the transport facilities in the city. Ogbomoso is the gateway to northern Nigeria from Lagos, the commercial capital of Nigeria. Unlike in every other major city where the Trunk A road connecting Lagos to the North passes through, it is a single carriage way in Ogbomoso leading to a partial collapse of the road because of the volume it carries. With Ibadan and Ogbomoso being the most populous cities in Oyo State, their relatively low performance in the education dimensions is attributable to the number of educational facilities relative to population size as well as poor female enrolment.

Afijio, Ibarapa East, Oorelope, Surulere, Ogo-Oluwa, Oriire and the periurban Ibadan LGAs of Oluyole, Lagelu, Ido, Akinyele, Onaara and Egbeda did not also witness any partitioning. While the performances of the majority of these set of LGAs were largely consistent in the pre- and post- partitioning eras, suggesting that the partitioning exercise elsewhere did not impact their development, a few of them had some significant movements. In the former category were the six peri-urban Ibadan LGAs. Just like the five metropolitan LGAs in the city, these LGAs did not record any significant movement in the period under review. Their proximity to the metropolitan LGAs did not reflect any trickle-down effects from the aggregate development profiles of the metropolitan LGAs, which account for $55 \%$ of the estimated $4.5 \mathrm{~m}$ population in the city. In contrast, Ogo-Oluwa, Surulere and Ibarapa East LGAs moved up the development ladder despite not being partitioned. The education campuses in Ogbomoso and Ibarapa East are likely to have influenced the positive movement in the three LGAs. Both Ogo-Oluwa and Surulere are in very close proximity to the Ladoke Akintola University of Technology established about five years before the partitioning exercise. In 25 years, the institution's positive externalities must have impacted socioeconomic development in its locational catchment area. The same applies in Eruwa (Ibarapa East) where the Adeseun Ogundoyin Polytechnic is situated.

Among the partitioned LGAs, the movements in terms of the development of the presented dimensions were more dramatic. Before the partitioning exercise of 1996, Irepo LGA was among the least developed local governments in the study area. It had its headquarters at Kishi town. Olorunsogo was carved out of Irepo and its administrative headquarters was situated at Igbeti. On the development dimensions, Irepo ranked among the least developed LGA pre-partitioning and post-partitioning, both Irepo and its offspring Olorunsogo were still in the least developed category. Like Irepo, Ifeloju LGA was also partitioned into two. The 
new LGA being Ibarapa North while the remaining space was renamed Ibarapa Central. Igboora remained the headquarters of Ibarapa Central while Ayete became the headquarters of the new LGA. Unlike in the Irepo case, however, Ibarapa Central moved from being among the least developed LGAs to being among the most developed after Ibarapa North was excised from it. The Ifeloju case suggests that that the low level of development in what now constitutes Ibarapa North LGA was widespread and had negative implications for the erstwhile Ifeloju LGA. From the analysis, other than on education and female education dimensions, none of the newly created LGAs featured in the top rank on the development dimensions of Social Services and Communication as well as Transport and Population.

Kajola with headquarters at Okeho belonged to the middle level of development in the 25 LGA era. It remained in the same category after the LGA creation exercise while Iwajowa that was created out of it ranked among the least developed LGAs. Pre-partitioning, Oyo, Ifedapo and Iseyin local governments were among the most developed LGAs on the 3-tiered development categorization in the study area. Oyo West LGA and Atiba LGA created from Oyo LGA were among the second tier LGAs after partitioning while the mother LGA, renamed Oyo East remained in the first tier. Similarly, Atisbo and Saki East excised from Ifedapo LGA were ranked second and third tier in development in the 33-LGA era while Ifedapo from which they were created (now named Saki West), remained among the most developed LGAs. Saki town remained the headquarters of Saki West as it was under Ifedapo. Iseyin also maintained its status in the first level while Itesiwaju LGA created from it belonged to the second level. This, again, suggests that most of the local government headquarters in the pre-partitioning period were already well developed and were merely carrying the burden of low development in the other settlements with which they shared a common jurisdiction. The partitioning exercise, therefore, reinforced their statuses as settlements of a higher level of development.

The results show an unequal development surface in the study area in the period before the last local government creation exercise of 1996 and afterwards. These suggest that jurisdictional partitioning does not automatically even-out unequal development in a space economy. Unlike the findings from other studies, where jurisdictional partitioning has been shown to aggravate further regional development disparities (Cho \& Kim, 2019; Rodriguez-Pose \& Ezcurra, 2010), evidence from this study shows that partitioning did not worsen the level of development in the local governments. The worst cases were a retention of the LGA's previous level of development prior to the partitioning exercise as witnessed with Irepo/Olorunsogo. The situation with the peri-urban Ibadan LGAs and Ogo-Oluwa and Surulere, that weren't partitioned, also indicates that partitioning exercises elsewhere within the state did not affect levels of development outside the partitioned jurisdictions. Instead, trickle-down effects from spatially congruent jurisdictions may positively impact levels of development in such other jurisdictions. With the emerged pattern of development in Kajola, Iseyin, Saki West and Oyo West where the erstwhile LGA headquarters in the old 
Kajola, Iseyin, Ifedapo and Oyo LGAs ensured that the mother LGAs retained their old ranking. At the same time, newly created spaces from them ranked lower in the post-partitioning era; decentralization provides a growth opportunity for previously undeveloped spaces within a jurisdiction that now constitute a separate jurisdiction. This aligns with Lessman's (2012) findings that while decentralization possesses the capacity to reduce regional inequality in development, the effect depends largely on the level of economic development of the jurisdictional space being decentralized as decentralization may actually result in higher regional inequalities.

In the overall analysis and when the numbers of jurisdictions on each of the ranking categories are compared, relative to the total number of LGAs, the creation of additional local governments in the study area had a positive impact on local development. In 1996, nine of the 25 LGAs (36\%) ranked among the least developed LGAs while $11(44 \%)$ ranked as most developed. A total of $20 \%$ of the LGAs were intermediate in their ranking. In 2016, the percentage of least developed LGAs had dropped to $24.4 \%$ while the number of most developed LGAs had risen to 12 from 11 . The most significant ranking improvement is noted in the intermediate category, where the proportion has risen from $20 \%$ to $39.4 \%$. These findings further provide evidence to support the arguments for the decentralization of governance for improved regional development. As shown elsewhere and at various scales, decentralization is an effective strategy for addressing local economic development (Okidi \& Guloba, 2006; Lessman, 2012; Ramesh, 2013; Cho \& Kim, 2019).

\section{Conclusion}

The decentralization of governance through the creation of additional local jurisdictions in Nigeria has been shown to positively impact the regional development of the country. However, beneath the general outlook of addressing local economic development, the impacts of decentralization on the spatial distribution of social services and public goods, and in addressing income inequality among spatial units should matter. This follows from the observation that in the study area, most of the LGAs in the post-partitioning period that ranked or retained their ranks as most developed LGAs still had their old LGA headquarters. This implies that the headquarters retained their initial advantage of the concentration of public investments and infrastructures while most of the newly created growth poles were at a disadvantage. This suggests that at an initial stage, decentralization exacerbates distributional inequality (du Plessis et al., 2018). Such inequality may be addressed by conscious planning efforts and other public policies in the long run. In other words, decentralization without a commensurate de-concentration of public investment and deliberate planning policies to address distributional inequality in the newly created jurisdictions may defeat the fundamental essence of the exercise. 


\section{Acknowledgement}

The authors appreciate the technical help of Misters Olaide Akande of the Federal University of Technology, Minna, Nigeria and Malachi Eze of the University of Nigeria.

\section{References}

Abdullahi, D. and Mahuta, M.M. (2012), "Local Government Creation and the Prospects of Area Development Board in Nigeria", Developing Countries Studies, vol. 2, no. 10, p. 41-47.

Adeniyi, E.O. (1985), "Regional Development Planning within the Context of National Development in Nigeria" in J.O. Abiodun (ed.) Urban and Regional Planning Problems in Nigeria, University of Ife Press, Ile-Ife, Nigeria.

Almond, G.A., Powell, G.B., Strom, K. and Dalton, R. (2003), Comparative Politics Today: A World view, Longman, New York.

Austin, C.M., Honey, R. and Eagle, T. (1987), Human Geography, West Publisher, New York.

Bahl, R.W. and Linn, J. F. (1992), Urban Public Finance in Developing Countries, Oxford University Press, New York.

Bailey, J.S. (1999), Local Government Economics: Principles and Practice, Macmillan Press Ltd, London.

Bailey, J.S. (2002), Public Sector Economics: Theory, Policy and Practice, Palgrave, New York.

Bailey, J.S. (2004), Strategic Public Finance, Palgrave, New York.

Bartlett, W., Maleković, S. and Monastiriotis, V. (2013), Decentralization and Local Development in South East Europe. Studies in Economic Transition, Palgrave Macmillan, Basingstoke, United Kingdom.

Biela, J., Hennel, A. and Kaiser, A. (2012), "Combining Federalism and Decentralization: Comparative Case Studies on Regional Development Policies in Switzerland, Austria, Denmark, and Ireland", Comparative Political Studies, vol. 45 , no. 4, p. 447-476.

Brancati, D. (2006), "Decentralization: Fueling the Fire or Dampening the Flames of Ethnic Conflict and Secessionism", International Organization, vol. 60, no. 3, p. 651-685.

Buchanan, J.M. (1974), The Limits of Liberty, Chicago University Press, Chicago.

Cho, J. and Kim, J.H. (2019), "Metropolitan Governance Structure and GrowthInequality Dynamics in the United States", EPA: Economy and Space 2019, vol. 51, no. 3, p. 598-616.

Coates, B.E., Johnston, R.J. and Knox, P.L. (1977), Geography and Inequality, Oxford University Press, London.

Cox, K.R. (1972), Man, Location and Behaviour: An Introduction to Human Geography, Wiley, New York. 
Danjuma, A. and Kwanga, Z.Y. (2012), "Developing Alternative Sources of Funding Local Governments during the Period of Global Economic Recession", Journal of Business and Management 2, (3), 36-40.

du Plessis, R., Milton, B.S. and Barr, B. (2018), "Devolution and the Regional Health Divide: a Longitudinal Ecological Study of 14 Countries in Europe", Journal of Public Health, vol. 41, no. 1, p. 3-9.

Eaton, K. (2001), "Political Obstacles to Decentralization: Evidence from Argentina and the Philippines", Development and Change, vol. 32, no. 1, p. 10128.

Eryilmaz, B. (2011), Public Administration, Okutman Publishing, Ankara.

Falleti, T.G. (2004), "A Sequential Theory of Decentralization and Its Effects on the Intergovernmental Balance of Power", Latin American Cases in Comparative Perspective, Working Paper, 314.

Federal Republic of Nigeria (1970), Second National Development Plan, 1970-1975, Federal Ministry of Information, Lagos.

Federal Republic of Nigeria (1975), Third National Development Plan, 1975-1980, Federal Ministry of Economic Development, Lagos

Federal Republic of Nigeria (1976), Guidelines for Local Government Reforms, Government Press, Kaduna

Fei, J.C.H and Ranis, G. (1961), "A Theory of Economic Development", American Economic Review, vol. 51, no. 4, p. 566-93.

Friedmann, J. (1966), Regional Development Policy; A Case of Venezuela, MIT Press, Massachusetts.

Harvey, D. (1973), Social Justice and the City, Edward Arnold, London.

Hirschman, A. (1958), The Strategy of Economic Development, Yale University Press, Yale.

Honey, R. (1983), "Versatility Versus Continuity - The Dilemma of Jurisdictional Change" in N. Kliot and S. Waterman (eds.), Pluralism and Political Geography: People, Territory and State, Croom Helm, London.

Ichimura, S. and Bahl, R. (2009), Decentralization Policies in Asian Development, World Scientific Publishing, Hackensack, New Jersey.

Ikporukpo, C.O. (1983), "Nigeria Regional Policies: Issues in Conception and Performance", Research for Development, vol. 3, no. 1, p. 63-75.

Ikporukpo, C.O. (1986), "Politics and Regional Policies: The Issue of State Creation in Nigeria", Political Geography Quarterly, vol. 5, no. 2, p. 127-139.

Joseph, I.O. (2014), "Decentralization, Local Governance and Public Goods Delivery in Nigeria", International Journal of Public Administration and Management Research, vol. 2, no. 2, p. 48-55.

Kim, A. (2008), "Decentralization and the Provision of Public Services", Framework and Implementation, Policy Research Working Paper, no. 4503, World Bank, Washington,

Köse, A.K. (2004), "The Case of Local Government and Rise in the Globalization Process", Sayistay Journal-Sayıștay Dergisi, vol. 52, p. 3-42.

Lago-Penas, I., Lago-Penas, S. and Martinez-Vazquez, J. (2011), "Guest Editorial", Environment and Planning C: Government and Policy, vol. 29, p. 197-203. 
Lessmann, C. (2012), "Regional Inequality and Decentralization: An Empirical Analysis", Environment and Planning A, vol. 44, p. 1363 - 1388.

Lewis, W.A. (1954), Economic Development with Unlimited Supplies of Labour, Manchester School of Economic and Social Studies, Manchester.

Mabogunje, A.L. (1980), The Development Process: A Spatial Perspective, Hutchinson, London

Mahalanobis, P.C. (1953), "Some Observations on the Process of Growth of National Income", Sankya, vol. 12, no. 4, p. 307-312.

Martinez-Vazquez, J. and McNab, R.M. (2003), "Fiscal Decentralization and Economic Growth", World Development, vol. 31, no. 9, p. 1597-1616.

Myrdal, G. (1957), Economic Theory and Underdeveloped Regions, G. Duckworth, London.

Okafor, S.I. (1987), "Jurisdictional Partitioning, Distribution Policies and the Spatial Structure of Health-Care Provision in Nigeria", Political Geography Quarterly, vol. 6, no. 4, p. 335-346.

Okidi, J.A. and Guloba, M. (2006), "Decentralization and Development: Emerging Issues from Uganda's Experience", Occasional Paper 31, Economic Policy Research Center, Kampala, Uganda.

Ola, R.F. (1984), Local Administration in Nigeria, Kegan Paul, London.

Olowu, D. (2007), "Decentralization and Urban Governance in West Africa", in D. Eyoh and R. Stren (eds.), Decentralization and the Politics of Urban Development in West Africa, Woodrow Wilson International Center for Scholars, Washington, D.C.

Oyewo, A.T. (1987), Nigeria Local Government Administration Practice and Management, Jator, Ibadan

Ozmen, A. (2014), "Notes to the Concept of Decentralization", European Scientific Journal, vol. 10, no. 10, p. 415-424.

Perroux, F. (1955), "Economic Space, Theory and Applications", Quarterly Journal of Economics, vol. 68, p. 89-104.

Rodriguez-Pose, A. and Ezcurra, R. (2010), "Does Decentralization Matter for Regional Disparities? A Cross-Country Analysis", Journal of Economic Geography, vol. 10, p. 619-644.

Rondinelli, D.A. (1981), "Government Decentralization in Comparative Perspective: Theory and Practice in Developing Countries", International Review of Administrative Science, vol. 47, no. 2, p. 133-45.

Rondinelli, D.A. (1999), "What Is Decentralization?" in J. Litvack and J. Seddon (eds.), Decentralization Briefing Notes, WBI Working Papers.

Rostow, W.W. (1960), The Stages of Economic Growth - A Non-Communist. Manifesto, Cambridge University Press, Cambridge.

Schneider, A. (2003), "Decentralization: Conceptualization and Measurement", Studies in Comparative International Development, vol. 38, no. 3, p. 32-56.

Sjamsuddin, S. and Noor, I. (2012), "Decentralization: A Question for Developing Countries", Public Policy and Administration, vol. 11, no. 1, p. 9-22.

Smith, B.C. (1985), Decentralization: The Territorial Dimension of the State, George Allen and Unwin, London. 
Smith, D.M, (1987), Geography, Inequality and Society, Oxford University Press, Oxford.

Tahina, R.N. (2015), "Decentralization: Problems and Solutions - Madagascar Evidence", IOSR Journal of Economics and Finance, vol. 6, no. 2, p. 1-9.

Wunsch, J. (2001), "Decentralization: Local Governance and Recentralization in Africa", Public Administration and Development, vol. 21, no. 4, p. 277-88. 